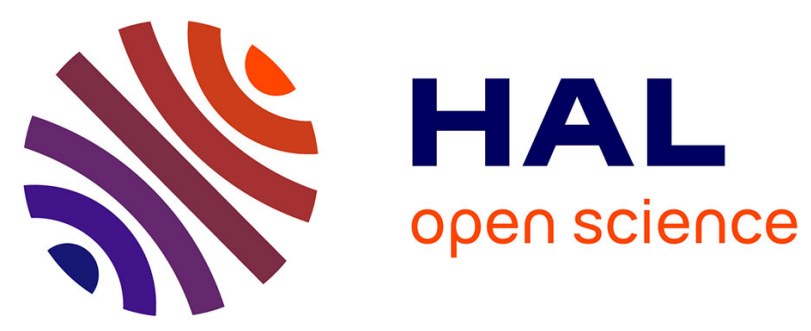

\title{
Characters from the deciduous dentition and its interest for phylogenetic reconstruction in Hippopotamoidea (Cetartiodactyla: Mammalia)
}

Helder Gomes Rodrigues, Fabrice Lihoreau, Maeva Orliac, Jean-Renaud Boisserie

\section{To cite this version:}

Helder Gomes Rodrigues, Fabrice Lihoreau, Maeva Orliac, Jean-Renaud Boisserie. Characters from the deciduous dentition and its interest for phylogenetic reconstruction in Hippopotamoidea (Cetartiodactyla: Mammalia). Zoological Journal of the Linnean Society, 2021, 193 (2), pp.413-431. 10.1093/zoolinnean/zlaa147 . hal-03405800

\section{HAL Id: hal-03405800 \\ https://hal.science/hal-03405800}

Submitted on 3 Nov 2021

HAL is a multi-disciplinary open access archive for the deposit and dissemination of scientific research documents, whether they are published or not. The documents may come from teaching and research institutions in France or abroad, or from public or private research centers.
L'archive ouverte pluridisciplinaire HAL, est destinée au dépôt et à la diffusion de documents scientifiques de niveau recherche, publiés ou non, émanant des établissements d'enseignement et de recherche français ou étrangers, des laboratoires publics ou privés. 
Characters from the deciduous dentition and its interest for phylogenetic reconstruction in Hippopotamoidea (Cetartiodactyla, Mammalia)

Helder GOMES RODRIGUES ${ }^{1,2}$, Fabrice LIHOREAU1 ${ }^{1}$, Maëva ORLIAC ${ }^{1}$, Jean-Renaud BOISSERIE ${ }^{3,4}$

${ }^{1}$ Institut des Sciences de l'Evolution de Montpellier (ISEM), Univ Montpellier, CNRS, IRD, Montpellier, France

${ }^{2}$ Centre de Recherche en Paléontologie - Paris (CR2P), UMR CNRS 7207, CP38, Muséum national d'Histoire naturelle, Sorbonne Université, 8 rue Buffon, 75005 Paris, France.

${ }^{3}$ Laboratoire Paléontologie Evolution Paléoécosystèmes Paléoprimatologie, CNRS, Université de Poitiers - UFR SFA, Bât B35 - TSA 51106, 86073 Poitiers Cedex 9, France

${ }^{4}$ Centre Français des Études Éthiopiennes, CNRS, Ministère de l'Europe et des affaires étrangères - PO BOX 5554, Addis Abeba, Éthiopie

\section{Corresponding author:}

Helder Gomes Rodrigues

Email address: helder.gomes-rodrigues@mnhn.fr

Telephone: +33140793814 


\begin{abstract}
Teeth are frequently used in phylogeny in order to better characterize the evolution of extinct mammal species. While most studies focused on the adult dentition, the consideration of characters from the deciduous dentition could also contribute to reinforce phylogenetic assumptions or disentangle phylogenetic issues. We thus chose to investigate the characters of the deciduous dentition in cetartiodactyl taxa in relation to the disputed relationships within hippopotamoids, especially the position of Hippopotamidae. We described the deciduous dentition of 51 species, among a dataset of 70 cetartiodactyls. We noticed that second and third deciduous premolars have a much lower degree of molarization, and are more suitable for coding than fourth deciduous premolars. Thirty-nine resulting characters were thus added to a previously published matrix, and parsimony and maximum-likelihood analyses were performed. Both analyses provided a better resolved topology for most taxa than without these characters, and with better supports for most nodes in the parsimony analysis. Moreover, this analysis provides additional characters supporting the hypothesis of an emergence of hippopotamids within bothriodontine anthracotheres from the Paleogene of Africa. The promising use of characters from the deciduous dentition in phylogeny should allow discussing the underlying ontogenetic mechanisms at the origin of dental homology.
\end{abstract}

Keywords: Anthracotheres, Dental ontogeny, Hippopotamidae, Homology, Maximumlikelihood analysis, Molarization, Parsimony analyses 


\section{INTRODUCTION}

Mammals are notably known for the high morphological complexity and heterogeneity of their dentition (e.g. Luo 2007; Ungar 2010). Their teeth are commonly used for taxonomic purposes, and several phylogenetic analyses are based on characters from the adult dentition and involving both extinct and extant species. The occlusal morphology of the deciduous dentition was also demonstrated to provide a high number of relevant characters for phylogenetic reconstructions (Guanfang and Schmidt-Kittler 1983; Benefit 1994; Van der Made 1996; Sallam et al. 2016; Rose et al. 2018). Unfortunately, these characters remain understudied because they are frequently missing (Geraads et al. 1987; Luckett and Hong 1998; Theodor and Foss 2005; Borths and Stevens 2017), while they could constitute new sources of information to clarify phylogenetic issues that are the subject of longstanding discussions.

Among extant mammals, Cetartiodactyla comprise ruminants, camelids, suoids, hippopotamids, and cetaceans. The origins of these extant taxa and their phylogenetic relationships with extinct relatives have been widely studied, but there is no consensus, especially regarding the origins of hippopotamids, as well as cetaceans (Naylor and Adams 2001; Theodor and Foss 2005; Spaulding et al. 2009; Boisserie et al. 2011; Gatesy et al. 2013; Lihoreau et al. 2015). The deciduous premolars (DPs) of cetartiodactyls present a wide range of variation from simple to highly complex shapes, mimicking molars. Their DPs are less complex or molarized than in other ungulates, such as perissodactyls, which show a very high degree of molarization of both deciduous and permanent premolars (Butler 1952a; Rose et al. 2018), and thus a higher degree of co-variation among morphological traits from one tooth to another. The important gradient of molarization of DPs observed in a given species of cetartiodactyls, and also between cetartiodactyl taxa, would potentially imply a lower level of co-variation between chosen characters, which would render them more suitable for phylogenetic reconstructions (e.g., Billet and Bardin, 2019). These observations make the DPs 
of cetartiodactyls potentially relevant for integration in future phylogenetic studies.

Here, we aim at testing the use of characters related to the morphology of the deciduous dentition in phylogenetic studies dealing with the origin and relationships within Hippopotamoidea (extinct "Anthracotheriidae" + Hippopotamidae), compared to more traditional characters associated with the permanent dentition. To do so, we base our analyses on a modified version of the recent phylogeny initially produced by Lihoreau et al. (2015) and then updated (e.g., Lihoreau et al, 2019), focusing mostly on hippopotamoids, but also involving early diverging Paleogene cetartiodactyls. The associated matrix mainly relies on dental characters, but also includes a few cranial characters. This study describes the primary morphotypes of DPs observed during the evolution of hippopotamoids and some other cetartiodactyls (except cetaceans). The influence of these new characters on the phylogenetic relationships between the studied cetartiodactyl taxa are then evaluated, especially concerning the suggested emergence of hippopotamids from bothriodontine anthracotheriids (e.g., Lihoreau et al. 2015; Boisserie et al. 2017a).

\section{MATERIAL AND METHODS}

The deciduous dentition of 55 species of cetartiodactyls (corresponding to 51 taxa in the matrix), including 29 hippopotamoids, was investigated (Table 1, Table S1, Figures 1 and 2). Data on deciduous premolars were obtained from material housed in different institutions (AMNH: American Museum of Natural History, New York, USA; ARCCH: National Museum of Ethiopia/Authority for Research and Conservation of the Cultural Heritage, Addis Ababa, Ethiopia; CNRD: Centre National de Recherche pour le Développement, N’Djaména, Chad; FSL: Faculté des Sciences of Lyon; HPM: Harvard Peabody Museum, Cambridge; Museum für Naturkunde, Berlin; Museum of Natural History, Bern; MNHN: Muséum National d'Histoire Naturelle, Paris; MNHT: Muséum d'Histoire Naturelle, Toulouse; MOBE, Muséum d'Orléans 
pour la biodiversité et l'environnement, Orléans; Museum Crozatier,Le Puy-en-Velay, France; NHM: Natural History Museum, London, United Kingdom; NMK: National Museums of Kenya, Nairobi; ONM: Museum of the Office National des Mines, Tunis, Tunisia; RMCA: Royal Museum of Central Africa, Tervuren, Belgium; RR: Ranga Rao collection, Dehra Dun, India; SMNS: Staatliches Museum für Natürkunde, Stuttgart, Germany; UM: University of Montpellier; University of Poitiers) and from previously published studies (Table 1, Table S1).

Height new taxa, for which the deciduous dentition is well documented, were added to the original matrix of Lihoreau et al. (2015), updated in more recent studies (Lihoreau et al. 2017, 2019; Boisserie et al. 2017a, 2017b, Boisserie and Bibi, in press): Acotherulum saturninum, Anoplotherium commune, Bachitherium lavocati, Choeropotamus parisiensis, Choeropsis liberiensis, Egatochoerus jaegeri, Hippopotamus amphibius, Prodremotherium elongatum. The final dataset consists of 70 taxa, including 40 hippopotamoids, and we collected data for DPs for 51 out of these 70 taxa (including 29 hippopotamoids; Table 1). The dental eruption pattern of cetartiodactyls has recently been studied and demonstrated as having a strong phylogenetical signal considering both extinct and extant families (Monson \& Hlusko et al. 2018; Gomes Rodrigues et al. 2019). In this study, one character consists of the dental eruption pattern discussed in Gomes Rodrigues et al. (2019; Figure 3A, Appendix 1), while the remaining 38 dental characters are new features (21 for the lower deciduous premolars, and 17 for the upper deciduous premolars, Figure 3B, C; Appendix 1). A new character related to $\mathrm{p} 1$ morphology was also added (character 17: p1 caniniform - $17^{0}$ No, $17^{1}$ Yes), which brings to 221 the total number of characters in the new matrix (Appendix S1). The dental nomenclature used follows Boisserie et al. (2010), and includes a complementary terminology regarding the deciduous dentition (Figure 3B, C). Px and Mx refer to the xth upper premolars and molars, px and mx to the xth lower premolars and molars, and Pxs for both upper and lower teeth, with a D/d indicating deciduous teeth. 
Two parsimony analyses were performed on the matrix (Appendix S2) including or omitting the characters of the deciduous dentition (unordered and unweighted), and using PAUP 4.0a167 (Figure 4; Swofford 2002). These heuristic searches took polymorphisms into account, and were performed for 1000 replicates with random addition sequence. Bremer supports were also calculated to test the robustness of each node up to five supplementary steps. Consistency and retention indexes are provided for trees (CI and RI) and for characters (ci and ri). Only the significance of characters related to the DPs was measured (Appendix S3), but not the characters already investigated in previous studies (see Lihoreau et al. 2015). A maximumlikelihood analysis was also performed with RaxML v0.9.0 (Kozlov et al., 2019) on the same data matrix. As RaxML does not accept polymorphism for morphological data, these were changed to the most common state in the smallest systematic group (tribe or subfamily) that includes the taxon, resulting in $10 \%$ changes with respect to the matrix used for parsimony analyses (Appendix S4). We then performed 1000 bootstraps to assess node supports (Figure $5)$.

\section{RESULTS}

\section{Patterns of morphological variation among deciduous premolars and choice of characters}

The DP4 presents the same morphology as the M1, even if it has a smaller size and slightly different proportions, with a shorter length of the lingual margin (Figure 1). The morphology of dp4 is also very similar to $\mathrm{m} 1$ in its distal part (Figure 2). The main difference between $\mathrm{dp} 4$ and $\mathrm{m} 1$ relies on the presence of a prelobe mesially including a paraconid in labial position and a primoconid in lingual position (Figure 3B), missing in the investigated species of Diacodexis (i.e., D. indicus). According to the high degree of similarity between DP4s and M1s, the DP4s were not coded, except the prelobe of dp4, which is missing in lower molars. We also consider the development of the root located under the protoconid on dp4, which is 
variable among the different families, and was recently mentioned as having a potential phylogenetic interest (Orliac et al. 2015; Pickford 2018).

The DP3 of the investigated cetartiodactyls initially includes a paracone, a metacone, and a distally located protocone. It can also be more complex with the development of a parastyle, which can be doubled by a second lingual parastyle in late diverging anthracotheriids (Merycopotamus and Libycosaurus), and also with the development of a postparaconule in some hippopotamoids or a metaconule in cainotheriids (Figure 3C, Table 2). The dp3 varies from simple to complex with the sole protoconid, and followed by the development of the hypoconid, and then of the paraconid and entoconid (Figure 3B, Table 2). The DP2 can be simple with only the paracone, to complex with the addition of a metacone, a postparaconule in late diverging anthracotheriids (Merycopotamus and Libycosaurus), a parastyle, and a protocone (Figure 3C, Table 2). Similarly, the dp2 can be simple, with only the protoconid present, or more complex with the presence of the paraconid and/or the hypoconid (Figure 3B, Table 2).

The DP1s were not considered, because they are generally very simple, occasionally missing, and difficult to identify when isolated. As a result, we chose to mainly focus our characters on DP2-3s, in which the morphology is strongly different from both permanent premolars and molars. We thus coded features of the main cusps and crests, reflecting different morphotypes that are not represented in permanent premolars or molars, and corresponding to different degrees of morphological complexity (Appendix 1). More generally, there are $25 \%$ of missing data in the whole matrix. More precisely, characters related to DP morphology represent $50 \%$ of missing data, and others characters represent $20 \%$ of missing data.

\section{Phylogenetic analyses}

In the parsimony analyses, we obtained a better resolution for the phylogeny involving 
the use of DP characters (624 trees, 1486 steps, $C I=0.21, \mathrm{RI}=0.63$; Appendix S3) than for the other (1836 trees, 1277 steps, $\mathrm{CI}=0.19, \mathrm{RI}=0.64$ ), because there are fewer polytomies (Figure 4). The topology deriving from the analysis including characters from DPs mainly differs from the other by the well-supported monophyly of hippopotamoids (node A; Bremer support value of 3), which appear as sister group of the clade including notably ruminants (node J; Figure 4A). The subsequent nodes among hippopotamoids (B, C, and D) are also fairly well-supported (Bremer support values of 2, 3, and 3 respectively), as well as the highly robust node E defining the Bothriodontinae+Hippopotamidae (Bremer support value $>5$ ). Within hippopotamoids, all Brachyodus and Bothriogenys species appear as sister taxa to Epirigenys and hippopotamids, but this clade (node F) is weakly supported (Figure 4A). Conversely, only Bothriogenys orientalis and Epirigenys appear as the early offshoot of hippopotamids in the analysis without these characters, and early diverging anthracotheres are not grouped together with the clade Bothriodontinae+Hippopotamidae in the latter configuration (Figure 4B). However, among hippopotamines (node I: Chororatherium, Chorora hippopotamine, Archaeopotamus, Hexaprotodon, Hippopotamus, Choeropsis), relationships are better resolved in the analysis without characters from DPs, but with weak supports (Figure 4B). Other results from the analyses using DP characters are worth noticing (Figure 4A): suoids are monophyletic and in the same clade (node L) as Raoellidae (i.e. Indohyus and Khirtaria) and Entelodon; Anoplotheriidae (i.e. Diplobune, Dacrytherium, and Anoplotherium) are monophyletic, but weakly supported (node K), with Mixtotherium as sister taxa; and Choeropotamidae sensu lato (i.e. Choeropotamus, Amphirhagatherium, Hallebune) are polyphyletic. It can also be noticed that the investigated ruminants (i.e. Archaeomeryx, Lophiomeryx, Prodremotherium, Bachitherium) are paraphyletic in this configuration, but polyphyletic in the topology obtained without DP characters.

Most of the new characters included in this analysis show a high level of homoplasy, 
with 32 out of 39 characters showing a low ci (ci<0.5, Appendix S3). However, the ri of most of these characters (28 out of 39) show that this homoplasy is well-structured (ri $>0.5)$. The character concerning dental eruption is not informative regarding the phylogenetic relationship between anthracotheriids and hippopotamids, but it supports the monophyly of hippopotamids (183 ${ }^{1}$ : Eruption of M3s before or simultaneous to P4s only). Among the 38 chosen characters from the deciduous dentition, 20 informative characters support different clades involving both anthracotheriids and hippopotamids (nodes A: 3 characters; node B: 1; node C: 3; node E: 8; node F: 4, node G: 3; Figure 4A, see Appendix S3 for more details). Eleven of these 20 characters represent apomorphies shared by most anthracotheriids and hippopotamids and the corresponding state is mentioned for each taxon in association with the phylogeny (node $\mathrm{C}$ $211^{1}$ : preparacrista mesio-labially oriented on DP3; node E - $185^{0}$ : hypoconid missing on dp2, $187^{2}$ : mesio-lingual paraconid on $\mathrm{dp} 3,188^{1}$ : postprotocristid reaching the lingual side on $\mathrm{dp} 3$, $193^{1}$ : presence of an entoconid on dp3,219 ${ }^{1}$ : protocrista moderately protruding mesio-lingually in the valley on DP3; node F - $189^{1}$ : presence of a cingulid and/or entostylid on the lingual side of the protoconid on $\mathrm{dp} 3 ; 195^{2}$ : postentocristid labially oriented on $\mathrm{dp} 3 ; 199^{1}$ : paraconid and primoconid at the same level on dp4; node $\mathrm{G}-186^{1}$ : division of the distalmost cristid on $\mathrm{dp} 2$; 198 : absence of a root under the protoconid on dp4; Figures 3 and 4A, Appendix S3). These shared characters mostly concern the lower deciduous premolars, especially the dp3, which involve three character states exclusively present in anthracotheriids and hippopotamids $\left(187^{2}\right.$, $189^{1}, 195^{2}$ ). They also concern the dp2 to some extent, but characters from these deciduous premolars involve a lot of missing data. Our results also show that even if hippopotamids and suoids present similar character states from DPs, they are not related, because these similarities are characterized by either plesiomorphies or reversions. These characters are represented by the monocusped DP2s, involving the regression of the paraconid and hypoconid on dp2 and the metacone on DP2 (e.g. characters $184^{0}, 185^{0}, 205^{\circ}$ ); the reduction or loss of many crests in dp3- 
4 (e.g. characters $191^{0}, 194^{0} ; 200^{0} ; 202^{1}$ ); in addition to the missing root under the protoconid on dp4 (character $\left.198^{0}\right)$.

The maximum-likelihood analysis provides a topology (Figure 5) close to the strict consensus tree obtained from the parsimony analysis involving DP characters, even if a few clades are not retrieved (e.g., nodes J and L), and new clades appear (e.g., cebochoerids+suoids; Choeropotamus species+hippopotamoids), but with low bootstrap support values $(<50)$. Most of the main clades of hippopotamoids observed in the parsimony analyses are retrieved (nodes A to I), even if most of them show low bootstrap support values, especially within bothriodontines (nodes A, B, C, and D). There are only subtle differences in relationships within bothriodontines+hippopotamids (Figure 5). Relationships within hippopotamines (node I) are however better resolved than in the parsimony analysis.

\section{DISCUSSION}

\section{New support for the Bothriodontinae-Hippopotamidae clade}

The comparison of phylogenetic analyses, using either parsimony or maximumlikelihood methods, shows that inclusion of characters from the deciduous dentition enhances resolution of the internal relationships. Our parsimony analysis with DPs also displays a better support for relationships within hippopotamoids, especially the first nodes (A, B, C, D, Figure 4A) compared to previous studies in which they were weakly supported (Boisserie et al. 2017a, 2017b; Lihoreau et al., 2017, 2019). These differences might be explained by the inclusion of an important number of new characters, which might compensate the addition of new taxa in these analyses, compared to the first analysis by Lihoreau et al. (2015). As in all these previous studies, the Bothriodontinae-Hippopotamidae clade (node E) is still well supported using both methods. Moreover, we noticed that at least eleven characters from the DPs, especially the lower ones, support a close relationship between some anthracotheriids and the 
Hippopotamidae, including five characters for the Bothriodontinae-Hippopotamidae clade. Among these eleven characters, some states are only noticed in hippopotamoids and should be particularly important to consider in future systematic studies (e.g., mesio-lingual paraconid on dp3, presence of a cingulid and/or entostylid on the lingual side of the protoconid on $\mathrm{dp} 3$; postentocristid labially oriented on dp3; preparacrista mesio-labially oriented on DP3).

Among the characters supporting a close relationships between some bothriodontines and the Hippopotamidae, the character corresponding to the presence of $\operatorname{root}(\mathrm{s})$ under the protoconid on the dp4 (198) is one of the most striking examples. The emergence of Hippopotamidae is a longstanding debate, and main hypotheses favoured either the “Anthracotheriidae” or Suoidea (e.g. Matthew 1929; Colbert 1935; Gentry and Hooker 1988; Orliac et al. 2010; Pickford 2011, 2015; Lihoreau et al. 2015, Boisserie et al., 2005a; 2017a), even if most recent studies argued for an anthracotheriid origin. A recent study (Pickford 2018) still precluded the anthracotheriid hypothesis notably on the basis of the absence of root under the protoconid on the dp4 of Hippopotamidae compared to anthracotheriids, and we thus chose to add this character (198) in our analysis. The sample previously studied was small (one hippopotamid and seven anthracotheriids; Pickford 2018), whereas many more species are included in the present study (six hippopotamids and 13 anthracotheriids). Conversely to most anthracotheriids, we do find evidence for the absence of this root in the anthracotheriid Bothriogenys fraasi (Sallam et al. 2016), as well as in the questioned bothriodontine taxon, Qatraniodon (see Pickford 2018), long included in the genus Bothriogenys (Ducrocq 1997). Interestingly, Bothriogenys, with Epirigenys, are considered in our study and in previous analyses (Lihoreau et al. 2015; Boisserie et al. 2017a), as closely related to Hippopotamidae, meaning that this root was probably lost early in this family. The convergent patterns observed between hippopotamids and suoids also include the absence of this root. However, these convergences are more likely related to reversion or simplification of some characters of the 
DPs in hippopotamids, as previously observed for molars (Orliac et al. 2010; Boisserie et al. 2010; Lihoreau et al. 2015).

The results of both parsimony and maximum-likelihood analyses more deeply anchor the hippopotamids within Paleogene bothriodontines mostly evolving in Africa. This is suggested by the relationships of hippopotamids with African Bothriogenys (B. fraasi, B. gorringei), in addition to Epirigenys and the Asian $B$. orientalis, even if this clade still shows low Bremer and bootstrap support values. This configuration was first mentioned in the maximum-likelihood analysis of Lihoreau et al. (2015) involving Epirigenys and in the parsimony analysis of Boisserie et al. (2017a) including basal hippopotamines from Chorora. As a result, the use of characters from DPs provides additional support for this topology. It also strengthens the paleobiogeographic scenario previously proposed (see Lihoreau et al., 2015), which suggests an African hippopotamoid clade at the origin of Hippopotamidae probably issued from one or two dispersal events from southeastern Asia near the Eocene-Oligocene boundary.

Relationships within hippopotamines remains poorly resolved or poorly supported, depending on the parsimony analyses, while a better resolution is obtained with the maximumlikelihood analysis. This result might be more related to the inclusion of extant species (Hippopotamus amphibius, Choeropsis liberiensis) in our study, than to the choice of characters. It could also be explained by the lack of Plio-Pleistocene hippopotamine taxa in our analyses, especially aff. Hippopotamus or Hippopotamus species (Boisserie, 2005b, 2007, 2017), which could permit to fill the gap between late Miocene and extant hippopotamines species and solve the internal relationships.

Contrary to previous studies (Orliac et al., 2010; Lihoreau et al. 2015; Boisserie et al. 2017a) and the present maximum-likelihood analysis, Choeropotamus no longer appears as the sister taxon of hippopotamoids, despite their common derived state for dental eruption pattern 
(183²; Gomes Rodrigues et al. 2019). Both species of Choeropotamus are sister group of the clade of Paleogene cetartiodactyls including ruminants in the parsimony analysis. Choeropotamids (i.e. Choeropotamus, Amphirhagatherium, Hallebune, see Hooker and Thomas 2001) are polyphyletic, as in recent phylogenetic studies (Gatesy et al. 2013; Lihoreau et al. 2015; Luccisano et al., 2020), which stresses the need for revising this family. It seems however difficult to discuss on a fair basis other relationships among Paleogene cetartiodactyls given our data (e.g., the paraphyly of early ruminants, the monophyly of anoplotheriids, or the clade unifying Entelodon, Raoellidae and Suoidea). This study mainly focuses on hippopotamoids, and thus many families of cetartiodactyls are represented by only one or few species, and some high-ranked taxa are missing, such as archaeocetes (i.e. early diverging cetaceans), camelids, as well as some extinct northern American families (e.g., Protoceratidae) or extant families (Tragulidae, Bovidae, Cervidae).

\section{Relevance of using characters from the deciduous dentition}

The deciduous characters represent an original source of phylogenetic characters which complement the characters defined for molars, inasmuch as they belong to the same dental generation (Butler 1939; Järvinen et al. 2009). They notably depart from molars, with the inclusion of additional characters, such as the prelobe of the dp4, or the lingual parastyle and the postparaconule on the DP3. The different degrees of molarization observed, which increases from DP2s to DP4s, is also useful for the choice of characters and for characterizing the different morphotypes (Figure 3B, C). It is notably based on the main differences with molars, and principally on the absence or presence of main cusps. For instance, there are one to three cusps in dp2, one to four cusps in dp3, one to four cusps in DP2, and three to six cusps in DP3. DPs also differ from the permanent premolars in the shape, and in their more derived morphotypes, in having for instance many more cusps for a given species-specific locus, 
contrary to most perissodactyls in which permanent premolars are highly molarized as the deciduous generation (e.g. Butler 1952a,b; Rose et al. 2018).

The interest of using characters from deciduous premolars in Cetartiodactyla was first emphasized by Luckett and Hong (1998). They highlighted the special structural, functional and ontogenetic relationships of the DP3-4s and M1-2s complex, including the augmented dp4 (i.e. with three lobes), which is a characteristic of all extant and extinct "artiodactyls", not found in any other mammals. Then, Theodor and Foss (2005) highlighted the putative homology of denticles on dp2-3 in cebochoerids and archaeocete basilosaurids, which would give evidence for a potential relationships. However, their phylogenetic analysis suggested a parallel evolution of this character and they argued that it probably relies on a shared developmental pathway, which in fact rather corresponds to the patterning cascade mode of tooth cusp development illustrated by Jernvall (2000) in living seals. This hypothesis is supported here by a similar pattern observed in Anthracokeryx on dp3, Libycosaurus mesially on dp2, and even on DP2 of Elomeryx. Similarly, the postparaconule is convergently present in the DP3 (character $214^{1}$ ) of some anthracotheriids and in a few specimens of hippopotamids (Hippopotamus amphibius, and also Hexaprotodon sivalensis not investigated here), while this cusp is not observed in other cetartiodactyls. This cusp could also represent a case of parallel evolution specific to hippopotamoids. This latter characteristic, even if it does not represent a synapomorphy, might also indicate the existence of a close relationships between anthracotheriids and hippopotamids. It could thus represent a deep homology (Wake et al. 2011), which might be found in other extinct hippopotamids, and which needs further investigation.

The main issue regarding the use of characters from DP is the lack of data for many species, corresponding to half of missing data in the present matrix. This problem relies on both the scarcity of the material for deciduous teeth, and the under-investigation of this kind of data 
in previous studies. For instance, this high level of missing data might partly explain the polytomy observed in hippopotamids. In comparison, Borths and Stevens (2017), in their phylogenetic analysis of Hyaenodonta, had data on deciduous dentition for only $22 \%$ of taxa, but they found that these characters are phylogenetically informative. More generally, it means that these characters cannot be considered alone, but they represent a necessary complement to traditional data.

\section{Dental homology, developmental models and future prospects}

Like most Cenozoic mammals, the deciduous premolars of cetartiodactyls show a higher degree of complexity (or molarization) than permanent premolars, with distal DPs being much more complex than mesial DPs (Figures 1, 2, and 3B, C). This dentition patterning might be intimately related to specific developmental processes related to either morphogenetic fields (or gradient, Butler, 1939; Van Valen 1970) or degenerative migration of clone of cells (Osborn 1978). Interestingly, the order of cusp appearance is slightly different between adjacent teeth, but the order of appearance of first cusps remains similar to most other mammals, with the paracone and protoconid appearing first (Table 2; Butler 1956). As a result, even if variations exists regarding the mode of cusp and crest appearance, there is no need for a new terminology for DPs, compared to permanent premolars and molars, as proposed by Van der Made (1996) and Sallam et al. (2016), but contrary to Obergfell (1957) and Geraads et al. (1987). Our suggestion is based on the serial homology hypothesis, and on the development of cheek teeth (premolars and molars) that are probably initiated from the same field or very close fields (e.g. Butler 1939; 1967; Järvinen et al. 2009). Nonetheless, some hippopotamoids also show an additional cusp, the postparaconule, on DP2 and DP3; most of cetartiodactyls have a distally located protocone on these DP; and all artiodactyls have a prelobe on dp4. All these characters are always missing on molars. These observations mean that the underlying developmental 
mechanisms of the dentition patterning are more complex than those previously suggested (i.e. morphogenetic fields, clone of cells). These developmental or morphogenetic processes should be thus further investigated to revise these models, for a better comprehension and definition of dental homologies, and for the optimal use of associated dental characters in phylogenetic studies.

\section{CONCLUSION}

We showed that the resolution of phylogenetic relationships within hippopotamoids did benefit from the inclusion of characters from the deciduous dentition. Moreover, the hypothesis of hippopotamids rooted in African Paleogene bothriodontines is supported by both the parsimony and the maximum-likelihood analyses. We thus demonstrated that the study of the deciduous dentition is of high interest and a necessary complement to traditional dental characters to disentangle the evolutionary history of hippopotamoids. Some of these new characters representing either synapomorphy or putative deep homology in hippopotamoids are worth considering in both future phylogenetic and evo-devo studies to accurately understand their variation and their evolution in cetartiodactyls. A deeper investigation of these characters combined with the finding of additional Oligo-Miocene African bothriodontines, and the inclusion of Plio-Pleistocene hippopotamines in analyses, will certainly permit to improve the phylogenetic studies on hippopotamoids.

\section{REFERENCES}

Benefit BR. 1994. Phylogenetic, paleodemographic, and taphonomic implications of Victoriapithecus deciduous teeth from Maboko, Kenva. American Journal of Physical Anthropology 95:277-331.

Billet G, Bardin J. 2019. Serial Homology and Correlated Characters in Morphological 
Phylogenetics: Modeling the Evolution of Dental Crests in Placentals. Systematic Biology 68:267-280.

Boisserie, J-R. 2005b. The phylogeny and taxonomy of Hippopotamidae (Mammalia: Artiodactyla): a review based on morphology and cladistic analysis. Zoological Journal of the Linnean Society 143:1-26.

Boisserie, J-R. 2007. Family Hippopotamidae. In: Prothero DR, Foss SE, editors. The Evolution of Artiodactyls. Baltimore: Johns Hopkins University Press, p. 106-119.

Boisserie J-R. 2017. Hippopotamidae (Cetartiodactyla, Hippopotamoidea) from Kanapoi, Kenya, and the taxonomic status of the late early Pliocene hippopotamids from the Turkana Basin. Journal of Human Evolution 140:102377.

Boisserie J-R., Bibi F. in press. Hippopotamidae from the late Miocene Baynunah Formation. In: Bibi F, Kraatz B, Beech M, Hill A, editors. Sands of Time: Late Miocene Fossils from the Baynunah Formation. U.A.E.: Springer.

Boisserie J-R, Fisher RE, Lihoreau F, Weston EM. 2011. Evolving between land and water: key questions on the emergence and history of the Hippopotamidae (Hippopotamoidea, Cetancodonta, Cetartiodactyla). Biological Reviews 86:601-625.

Boisserie J-R, Kiarie C, Lihoreau F, Nengo I. 2017b. Middle Miocene Kenyapotamus (Cetartiodactyla, Hippopotamidae) from Napudet, Turkana Basin, Kenya. Journal of Vertebrate Paleontology 37:e1272055.

Boisserie J-R, Lihoreau F, Brunet M. 2005a. Origins of Hippopotamidae (Mammalia, Cetartiodactyla): towards resolution. Zoologica Scripta 34:119-143.

Boisserie J-R, Lihoreau F, Orliac M, Fisher R, Weston EM, Ducrocq S. 2010. Morphology and phylogenetic relationships of the earliest known hippopotamids (Cetartiodactyla, Hippopotamidae, Kenyapotaminae). Zoological Journal of the Linnean Society $158: 352-366$. 
Boisserie J-R, Schuster M, Beech MJ, Hill A, Bibi F. 2017c. A new species of hippopotamine (Cetartiodactyla, Hippopotamidae) from the late Miocene Baynunah Formation, Abu Dhabi, United Arab Emirates. Palaeovertebrata 41:e2. doi: 10.18563/pv.41.1.e2

Boisserie J-R, Suwa G, Asfaw B, Lihoreau F, Bernor RL, Katoh S, Beyene Y. 2017a. Basal hippopotamines from the upper Miocene of Chorora, Ethiopia. Journal of Vertebrate Paleontology 37:e1297718.

Borths MR, Stevens NJ. 2017. Deciduous dentition and dental eruption of Hyainailouroidea (Hyaenodonta, “Creodonta," Placentalia, Mammalia). Palaeontologia Electronica 20.3.55A:1-34.

Butler PM. 1939. Studies of the Mammalian Dentition.-Differentiation of the Post-canine Dentition. Proceedings of the Zoological Society of London B 109:1-36.

Butler PM. 1952a. Molarization of the premolars in the Perissodactyla. Proceedings of the Zoological Society of London 121:819-843.

Butler PM. 1952b. The milk-molars of Perissodactyla, with remarks on molar occlusion. Proceedings of the Zoological Society of London 121:777-817.

Butler PM. 1956. The ontogeny of molar pattern. Biological Reviews 31:30-70.

Butler PM. 1967. Comparison of the development of the second deciduous molar and first permanent molar in man. Archives of Oral Biology 12:1245-1260.

Colbert EH. 1935. Distributional and phylogenetic studies on Indian fossil mammals. 4, The phylogeny of the Indian Suidae and the origin of the Hippopotamidae. American Museum novitates 799:1-24.

Dineur H. 1981. Le genre Brachyodus, anthracotheriidae (Artiodactyla, Mammalia) du Miocène inférieur d'Europe et d'Afrique. Unpublished thesis, Université Paris 6.

Ducrocq S. 1997. The anthracotheriid genus Bothriogenys (Mammalia, Artiodactyla) in Africa and Asia during the Paleogene: phylogenetical and paleobiogeographical relationships. 
Stuttgarter Beiträge zur Naturkunde, B (Geologie und Paläontologie) 250:1-44.

Ducrocq S. 1999. The late Eocene Anthracotheriidae (Mammalia, Artiodactyla) from Thailand. Palaeontographica Abt. A 252:93-140.

\section{Gatesy J, Geisler JH, Chang J, Buell C, Berta A, Meredith RW, Springer MS, McGowen} MR. 2013. A phylogenetic blueprint for a modern whale. Molecular Phylogenetics and Evolution 66:479-506.

Gentry AW, Hooker JJ. 1988. The phylogeny of the Artiodactyla. In: Benton MJ, editor. The phylogeny and classification of the Tetrapods, volume 2 : mammals. Oxford: Clarendon press, p. 235-272.

Geraads D, Bouvrain G, Sudre J. 1987. Relations phylétiques de Bachitherium filhol, ruminant de l'Oligocène d'Europe Occidentale. Palaeovertebrata 17:43-73.

Gomes Rodrigues H, Lihoreau F, Orliac M, Thewissen JGM, Boisserie JR. 2019. Unexpected evolutionary patterns of dental ontogenetic traits in cetartiodactyl mammals. Proceedings of the Royal Society B: Biological Sciences 286:20182417.

Guanfang C, Schmidt-Kittler N. 1983. The deciduous dentition of Percrocuta KRETZOI and the diphyletic origin of the hyaenas (Carnivora, Mammalia). Paläontologische Zeitschrift 57:159-169.

Hellmund M. 1991. Revision der europäischen Species der Gattung Elomeryx Marsh, 1894 (Anthracotheriidae, Artiodactyla, Mammalia) - Odontologische Untersuchungen. Palaeontographica 220:1-101.

Hooker JJ, Thomas KM. 2001. A new species of Amphirhagatherium (Choeropotamidae, Artiodactyla, Mammalia) from the late Eocene Headon Hill formation of Southern England and phylogeny of endemic European 'anthracotherioids'. Palaeontology $44: 827-853$

Järvinen E, Tummers M, Thesleff I. 2009. The role of the dental lamina in mammalian tooth 
replacement. Journal of experimental zoology 312B:281-291.

Jernvall J. 2000. Linking development with generation of novelty in mammalian teeth. Proceedings of the National Academy of Sciences 97:2641.

Kozlov AM, Darriba D, Flouri T, Morel B, Stamatakis A. 2019. RAxML-NG: A fast, scalable, and user-friendly tool for maximum likelihood phylogenetic inference. Bioinformatics 35:4453-4455

Leidy J. 1852. The ancient fauna of Nebraska. A description of remains of extinct Mammalia and Chelonia, from the Mauvaises Terres of Nebraska. Washington: Smithsonian Institution.

Lihoreau F, Alloing-Séguier L, Antoine PO, Boisserie JR, Marivaux L, Métais G, Welcomme JL. 2017. Enamel microstructure defines a major Paleogene hippopotamoid clade: the Merycopotamini (Cetartiodactyla, Hippopotamoidea). Historical Biology 29:947-957.

Lihoreau F, Barry J, Blondel C, Chaimanee Y, Jaeger JJ, Brunet M. 2007. Anatomical revision of the genus Merycopotamus (Artiodactyla; Anthracotheriidae): Its significance for Late Miocene mammal dispersal in Asia. Palaeontology 50:503-524.

Lihoreau F, Boisserie JR, Blondel C, Jacques LL A, Mackaye HT, Vignaud P, Brunet M. 2014. Description and palaeobiology of a new species of Libycosaurus (Cetartiodactyla, Anthracotheriidae) from the Late Miocene of Toros-Menalla, northern Chad. Journal of Systematic Palaeontology 12:761-798.

Lihoreau F, Boisserie JR, Manthi FK, Ducrocq S. 2015. Hippos stem from the longest sequence of terrestrial cetartiodactyl evolution in Africa. Nature Communications $6: 6264$.

Lihoreau F, Essid EM, Khayati Ammar H, Marivaux L, Marzougui W, Tabuce R, Temani R, Vianey-Liaud M, Merzeraud G. 2019. The Libycosaurus (Hippopotamoidea, 
Artiodactyla) intercontinental dispersal event at the early late Miocene revealed by new fossil remains from Kasserine area, Tunisia. Historical Biology 1-13.

Luccisano V, Sudre J, Lihoreau F. 2020. Revision of the Eocene artiodactyls (Mammalia, Placentalia) from Aumelas and Saint-Martin-de-Londres (Montpellier limestones, Hérault, France) questions the early European artiodactyl radiation. Journal of Systematic Palaeontology, 18:1631-1656.

Luckett WP, Hong N. 1998. Phylogenetic relationships between the orders Artiodactyla and Cetacea: a combined assessment of morphological and molecular evidence. Journal of Mammalian Evolution 5:127-182.

Luo Z-X. 2007. Transformation and diversification in early mammal evolution. Nature 450:1011-1019.

MacDonald JR. 1956. The North American Anthracotheres. Journal of Paleontology. 30:615645.

Matthew WD. 1929. Reclassification of the Artiodactyl Families. GSA Bulletin. 40:403-408.

Miller JR, Wood AE. 1963. The Upper Deciduous Molars in Mid-Tertiary Oreodonts (Mammalia, Merycoidodontidae). Journal of Paleontology 37:705-713.

Monson TA, Hlusko LJ. 2018. The Evolution of Dental Eruption Sequence in Artiodactyls. Journal of Mammalian Evolution 25:15-26.

Naylor GJP, Adams DC. 2001. Are the Fossil Data Really at Odds with the Molecular Data? Morphological Evidence for Cetartiodactyla Phylogeny Reexamined. Systematic Biology 50:444-453.

Obergfell FA. 1957. Vergleichende Untersuchungen an Dentition und Dentale altburdigaler Cerviden von Wintershof-West in Bayern und rezenter Cerviden. Palaeontographica Abt. A 109:71-166.

Orliac M, Boisserie JR, MacLatchy L, Lihoreau F. 2010. Early Miocene hippopotamids 
(Cetartiodactyla) constrain the phylogenetic and spatiotemporal settings of hippopotamid origin. Proceedings of The National Academy of Science 107:1187111876.

Orliac M, Guy F, Chaimanee Y, Jaeger JJ, Ducrocq S. 2011. New remains of Egatochoerus jaegeri (Mammalia, Suoidea) from the late Eocene of Peninsular Thailand. Palaeontology 54:1323-1335.

Orliac M, Karadenizli L, Antoine PO, Sen S. 2015. Small hyotheriine suids (Mammalia, Artiodactyla) from the late early Miocene of Turkey and a short overview of early Miocene small suoids in the Old World. Palaeontologia Electronica 18.2.30A:1-18.

Osborn JW. 1978. Morphogenetic gradients: fields versus clones. In: Butler PM, Joysey KA, editors. Development, function and evolution of teeth. London: Academic Press; p. 171201.

Pickford M. 2007. Suidae and Hippopotamidae from the Middle Miocene of Kipsaraman, Kenya and other sites in East Africa. Paleontological Research 11:85-105.

Pickford M. 2011. Morotochoerus from Uganda (17.5 Ma) and Kenyapotamus from Kenya (13-11 Ma): implications for hippopotamid origins. Estudios Geológicos 67:523-540.

Pickford M. 2015. Encore Hippo-thèses: Head and neck posture in Brachyodus (Mammalia, Anthracotheriidae) and its bearing on hippopotamid origins. Communications of the Geological Survey of Namibia 16:223-262.

Pickford M. 2018. New evidence concerning relationships within Artiodactyla, Mammalia: radicular morphology of the dp/4. Historical Biology 30:119-136.

Rose KD, Holbrook LT, Luckett P. 2018. Deciduous premolars of Eocene Equidae and their phylogenetic significance. Historical Biology 30:89-118.

Sallam HM, Sileem AH, Miller ER, Gunnell GF. 2016. Deciduous dentition and dental eruption sequence of Bothriogenys fraasi (Anthracotheriidae, Artiodactyla) from the 
Fayum Depression, Egypt. Palaeontologia Electronica19.3.38A:1-17.

Soe AN. 2008. A new study of the anthracotheres (Mammalia, Artiodactyla) from Pondaung formation, Myanmar: systematics implications. Palaeovertebrata 36:89-157.

Spaulding M, O'Leary MA, Gatesy J. 2009. Relationships of Cetacea (Artiodactyla) Among Mammals: Increased Taxon Sampling Alters Interpretations of Key Fossils and Character Evolution. Plos One 4:e7062.

Swofford DL. 2002. PAUP*, Phylogenetic analysis using parsimony (*and other Methods). Sunderland: MA: Sinauer Associates.

Theodor JM, Foss SE. 2005. Deciduous Dentitions of Eocene Cebochoerid Artiodactyls and Cetartiodactyl Relationships. Journal of Mammalian Evolution 12:161-181.

Thewissen JGM, Bajpai S. Indohyus, Endemic Radiation of Raoellid Artiodactyls in the Eocene of India and Pakistan. In press

Ungar PS. 2010. Mammal Teeth: Origin, Evolution, and Diversity. Baltimore: The John Hopkins University Press.

Van der Made J. 1996. Listriodontinae (Suidae, Mammalia), their evolution, systematics and distribution in time and space. Contr. Tert. Quatern. Geol. 33:3-254.

Van Valen L. 1970. An Analysis of Developmental Fields. Developmental Biology 23:456477.

Wake DB, Wake MH, Specht CD. 2011. Homoplasy: from detecting pattern to determining process and mechanism of evolution. Science 331:1032-1035.

\section{Weppe R, Blondel C, Vianey-Liaud M, Escarguel G, Pélissié T, Antoine PO, Orliac MJ.} 2020. Cainotheriidae (Mammalia, Artiodactyla) from Dams (Quercy, SW France); phylogenetic relationships and evolution around the Eocene-Oligocene transition (MP19-MP21). Journal of Systematic Paleontology 18:541-572. 
Table 1 List of the taxa investigated for their permanent dentition and for their deciduous dentition when available. The origins (institutions listed in the material and methods, or references) of the studied deciduous dentition are also mentioned. References for data previously investigated are cited in brackets. Institutional abbreviations - AMNH: American Museum of Natural History, New York, USA; ARCCH: National Museum of Ethiopia/Authority for Research and Conservation of the Cultural Heritage, Addis Ababa, Ethiopia; CNRD: Centre National de Recherche pour le Développement, N’Djaména, Chad; FSL: Faculté des Sciences of Lyon; HPM: Harvard Peabody Museum, Cambridge; Museum für Naturkunde, Berlin; Museum of Natural History, Bern; MNHN: Muséum National d'Histoire Naturelle, Paris; MNHT: Muséum d'Histoire Naturelle, Toulouse; MOBE, Muséum d'Orléans pour la biodiversité et l'environnement, Orléans; Museum Crozatier,Le Puy-en-Velay, France; NHM: Natural History Museum, London, United Kingdom; NMK: National Museums of Kenya, Nairobi; ONM: Museum of the Office National des Mines, Tunis, Tunisia; RMCA: Royal Museum of Central Africa, Tervuren, Belgium; RR: Ranga Rao collection, Dehra Dun, India; SMNS: Staatliches Museum für Natürkunde, Stuttgart, Germany; UM: University of Montpellier.

\begin{tabular}{|c|c|c|c|}
\hline & Permanent dentition & Deciduous dentition & $\begin{array}{l}\text { Material for deciduous premolars (previously } \\
\text { investigated permanent premolars) }\end{array}$ \\
\hline \multicolumn{4}{|c|}{ Diacodexeidae } \\
\hline Diacodexis & D. pakistanensis & D. indicus & UM (see Lihoreau et al., 2015) \\
\hline Bunophorus & B. grangeri & & (see Lihoreau et al., 2015) \\
\hline \multicolumn{4}{|c|}{ Homacodontidae } \\
\hline Homacodon & H. vagans & & (see Lihoreau et al., 2015) \\
\hline
\end{tabular}




\section{Cebochoeridae}

\section{Cebochoerus}

Acotherulum

$$
\text { C. campichii }
$$

A. saturninum, A. sp.

\section{Anoplotheriidae}

\section{Diplobune}

Dacrytherium

Anoplotherium

\section{Dichobunidae}

Dichobune

\section{Choeropotamidae}

Amphiraghatherium

Choeropotamus parisiensis

Choeropotamus depereti

Hallebune

\section{D. minor \\ D. ovinum}

A. commune

D. leporina

\section{Cainotheriidae}

Paroxacron

P. valdense

\section{Xiphodontidae}

Xiphodon
A. weigelti, A. neumarkensis
C. parisiensis
C. depereti
H. krumbiegeli

\section{D. minor}

A. commune

A. louisi
C. minor, C. campichii

A. saturninum, $A$. sp.

$D$. ovinum, $D$. saturnini

D. leporina, D. sp.

C. parisiensis

UM, Weppe et al., 2019 (see Lihoreau et al., 2015)

MNHN, Paléothèque website (see Lihoreau et al.,

MNHN, UM, Theodor and Foss, 2005 (see Lihoreau et al., 2015)

MNHN, UM

UM (see Lihoreau et al., 2015)

UM (see Lihoreau et al., 2015)

MNHN, UM

NHM, UM, MNHN, Pickford, 2018 (see Lihoreau et al., 2015)

UM (see Lihoreau et al., 2015)

MNHN, UM

(see Lihoreau et al., 2015)

(see Lihoreau et al., 2015)
2015) 


\section{Mixtotheriidae}

Mixtotherium

Lophiomerycidae

Lophiomeryx

\section{Archeomerycidae}

Archeomeryx

\section{Gelocidae}

Prodremotherium

Bachitherium

Amphimerycidae

Amphimeryx

\section{Merycoidodontidae}

Merycoidodon

\section{Entelodontidae}

Entelodon

Raoellidae

Indohyus

Khirtharia

\section{Suoidea}

Egatochoerus
UM, MNHN (see Lihoreau et al., 2015)

L. chalaniati

L. chalaniati

A. optatus

P. elongatum

B. lavocati

A. murinus

M. sp.

E. magnum, E. deguilhemi

I. indirae

K. dayi, K. inflata, K. aurea
M. culbertsoni

E. magnum

I. indirae

elongatum

B. lavocati

UM

UM
E. jaegeri
UM, MNHN (see Lihoreau et al., 2015)

Leidy, 1852; Miller and Wood, 1963 (see Lihoreau et al., 2015)

MNHN (see Lihoreau et al., 2015)

RR, Thewissen et al., in press (see Lihoreau et al., 2015) (see Lihoreau et al., 2015) cast UM, Orliac et al., 2011 
Palaeochoerus

Perchoerus

Kenyasus

\section{"Anthracotheriidae"}

\section{Siamotherium}

Anthracotherium magnum

Anthracotherium chaimanei

Heptacodon

Microbunodon

Myaingtherium

Anthracokeryx tenuis

Anthracokeryx thailandicus

Aepinacodon

Bothriodon

Elomeryx borbonicus

Elomeryx crispus

Brachyodus onoideus

Brachyodus aequatorialis

Brachyodus depereti

Bothriogenys gorringei

Bothriogenys fraasi
P. quercyi
P. probus
P. quercyi
P. probus?

K. rusingensis

S. krabiense

A. magnum

S. krabiense

A. magnum

A. chaimanei

H. occidentalis

M. minimum

$M$. kenyapotamoides

A. tenuis

A. thailandicus

A. americanum

B. velaunum

E. borbonicus

E. crispus

B. onoideus

B. aequatorialis

B. depereti

B. gorringei

B. fraasi

H. curtus

M. minimum

A. tenuis

B. velaunum

E. crispus

B. onoideus

B. gorringei

B. fraasi
FSL, UM (see Lihoreau et al., 2015)

AMNH (see Lihoreau et al., 2015)

(see Lihoreau et al., 2015)

A. chaimanei

E. borbonicus

B. aequatorialis cast UM, Ducrocq, 1999 (see Lihoreau et al., 2015) MNHN (see Lihoreau et al., 2015)

cast UM, Ducrocq, 1999 (see Lihoreau et al., 2015) cast MNHN, MacDonald, 1956 (see Lihoreau et al., 2015)

Univ. Poitiers (see Lihoreau et al., 2015)

(see Lihoreau et al., 2015)

cast UM, Soe 2008 (see Lihoreau et al., 2015)

(see Lihoreau et al., 2015)

(see Lihoreau et al., 2015)

Museum Crozatier, MNHN, MNHT (see Lihoreau et al., 2015)

FSL, UM (see Lihoreau et al., 2015)

Hellmund, 1991 (see Lihoreau et al., 2015)

MNHN, NMB, MOBE, Dineur, 1981 (see Lihoreau et al., 2015)

NMK (see Lihoreau et al., 2015)

(see Lihoreau et al., 2015)

NHM (see Lihoreau et al., 2015)

Sallam et al., 2016 (see Lihoreau et al., 2015) 
Bothriogenys andrewsi Bothriogenys orientalis Afromeryx

Sivameryx africanus

Sivameryx palaeindicus

Hemimeryx blanfordi

Merycopotamus nanus

Merycopotamus dissimilis

Merycopotamus medioximus

Libycosaurus barhi

Libycosaurus anisae

Libycosaurus algeriensis

Epirigenys

\section{Hippopotamidae}

Morotochoerus

Kenyapotamus ternani

Kenyapotamus coryndonae Hexaprotodon

Archaeopotamus harvardi

Archaeopotamus qeshta

Chororatherium

Chorora hippopotamine

Hippopotamus

Choeropsis
B. andrewsi
B. andrewsi

B. orientalis

\section{A. zelteni}

S. africanus

S. palaeindicus

H. blanfordi

\section{M. nanus}

M. dissimilis

M. medioximus

L. barhi

L. anisae

L. algeriensis

E. lokonensis

M. ugandensis
K. ternani

K. coryndonae

H. garyam H. garyam

A. harvardi A. harvardi
A. qeshta

C. roobi

Chorora hippopotamine

H. amphibius

C. liberiensis
A. zelteni
S. africanus
S. palaeindicus

M. nanus

M. dissimilis

M. medioximus

L. barhi

L. anisae
Chorora hippopotamine

H. amphibius

C. liberiensis
SMNS (see Lihoreau et al., 2015, 2019)

(see Lihoreau et al., 2015)

NMK (see Lihoreau et al., 2015)

NMK (see Lihoreau et al., 2017)

HPM (see Lihoreau et al., 2015)

(see Lihoreau et al., 2017)

AMNH, Lihoreau et al., 2007 (see Lihoreau et al., 2015)

HPM, Lihoreau et al., 2007 (see Lihoreau et al., 2015)

HPM, Lihoreau et al., 2007 (see Lihoreau et al., 2017)

CNRD, Lihoreau et al., 2014 (see Lihoreau et al., 2015)

ONM (see Lihoreau et al., 2015)

(see Lihoreau et al., 2019)

(see Lihoreau et al., 2015)

(see Lihoreau et al., 2015)

NMK, Pickford, 2007 (see Boisserie et al., 2017b)

(see Lihoreau et al., 2015)

CNRD (see Lihoreau et al., 2015)

NMK (see Lihoreau et al., 2015)

Boisserie et al., 2017c (see Boisserie and Bibi, in press)

(see Boisserie et al., 2017a)

ARCCH (see Boisserie et al., 2017a)

RMCA, MNHN, NHM, Museum Bern

MNHN, NHM, NMK, Museum Berlin, Bern 
Table 2 Order of cusp appearance based on the different morphotypes of deciduous premolars (styles and stylids are not included). The first row represents the earliest appearance.

\begin{tabular}{|c|c|c|c|c|c|}
\hline $\mathrm{dp} 2$ & $\mathrm{dp} 3$ & $\mathrm{dp} 4$ & DP2 & DP3 & DP4 \\
\hline Protoconid & Protoconid & $\begin{array}{l}\text { Paraconid, Metaconid, } \\
\text { Protoconid, Entoconid, } \\
\text { Hypoconid }\end{array}$ & Paracone & $\begin{array}{l}\text { Paracone, Metacone, } \\
\text { "Protocone" }\end{array}$ & $\begin{array}{c}\text { Parastyle, Paracone, } \\
\text { Metacone, Protocone, } \\
\text { Paraconule, } \\
\text { Metaconule, }\end{array}$ \\
\hline \multirow[t]{2}{*}{ Paraconid/Hypoconid } & Hypoconid & Primoconid & Metacone & Parastyle labial & Hypocone \\
\hline & Entoconid & & "Protocone" & Parastyle lingual & \\
\hline
\end{tabular}


Figure 1 Upper deciduous dentition of cetartiodactyls presented in the same orientation. A $D$. leporina MNHN.F.GY654 (right), B E. magnum MNHN.F.Qu133 (right), C C. minor MNHN.F.Qu11283 (left), D D. minor UM ITD82 (left), E P. quercyi FSL8792 (right), F B. lavocati UM PDS1424 (right), G A. magnum MNHN.F.Qu1043 (left), H M. minimum Ma35168 (right), I B. velaunum MNHN.F.RZN202(right), J E. borbonicus FSL8479 (left), K A. harvardi KNM-LT00102 (right), L C. liberiensis OM6129 (right).

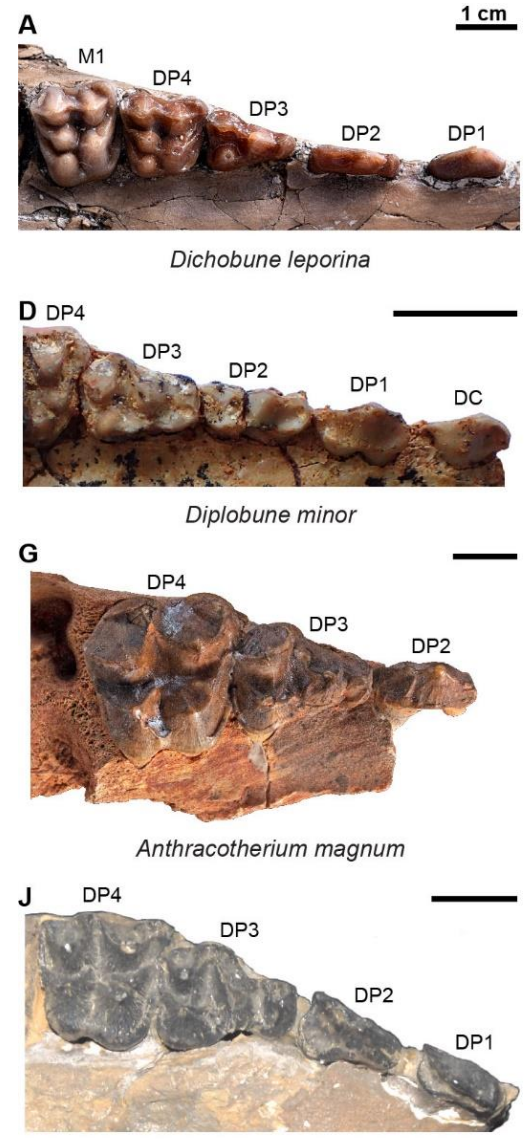

Elomeryx borbonicus
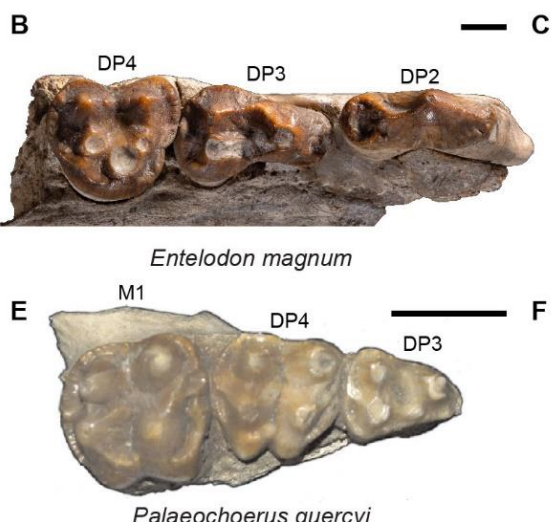

H

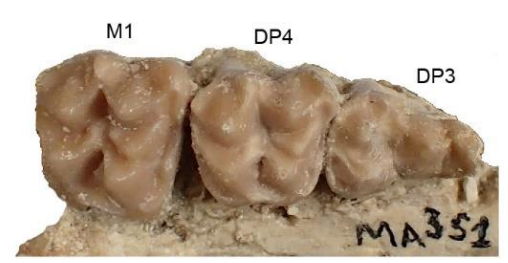

Microbunodon minimum

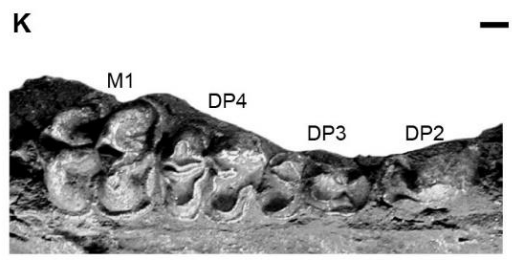

Archaeopotamus harvardi

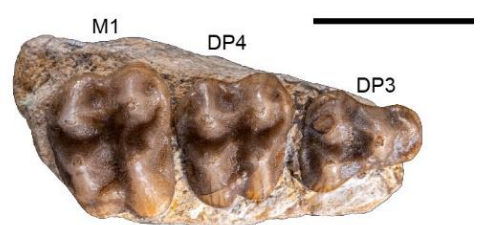

Cebochoerus minor
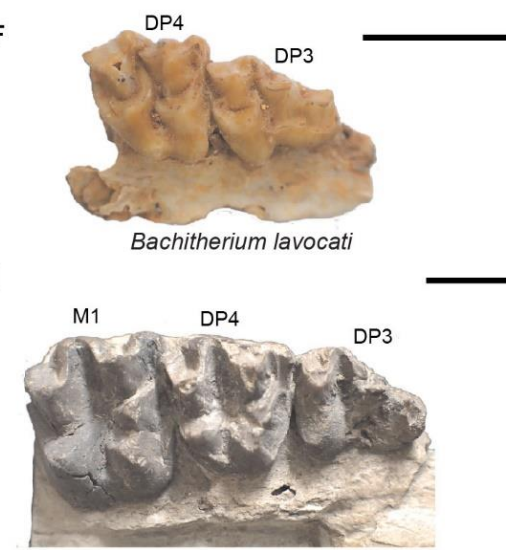

Bothriodon velaunum

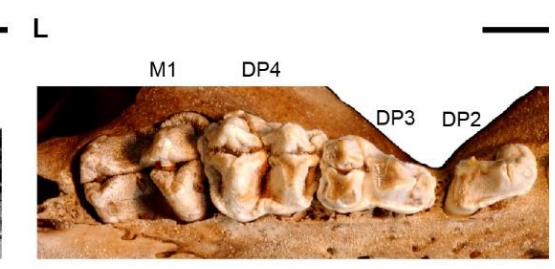

Choeropsis liberiensis 
Figure 2 Lower deciduous dentition of cetartiodactyls presented in the same orientation. A Dichobune sp. MNHN.F.Qu126 (left), B E. magnum MNHN.F.Qu43 (right), C C. minor MNHN.F.Qu53 (right), D D. minor UM ITD42 (left), E P. quercyi FSL8793 (left), F B. lavocati UM PDS1334 (left), G A. magnum MNHN.F.Qu17363 (right), H M. minimum Ma238-68 (left), I B. velaunum MNHN.F.RZN306 (left), J E. borbonicus FSL8921 (right), K A. harvardi KNMLT00001 (right), L C. liberiensis OM6129 (left).
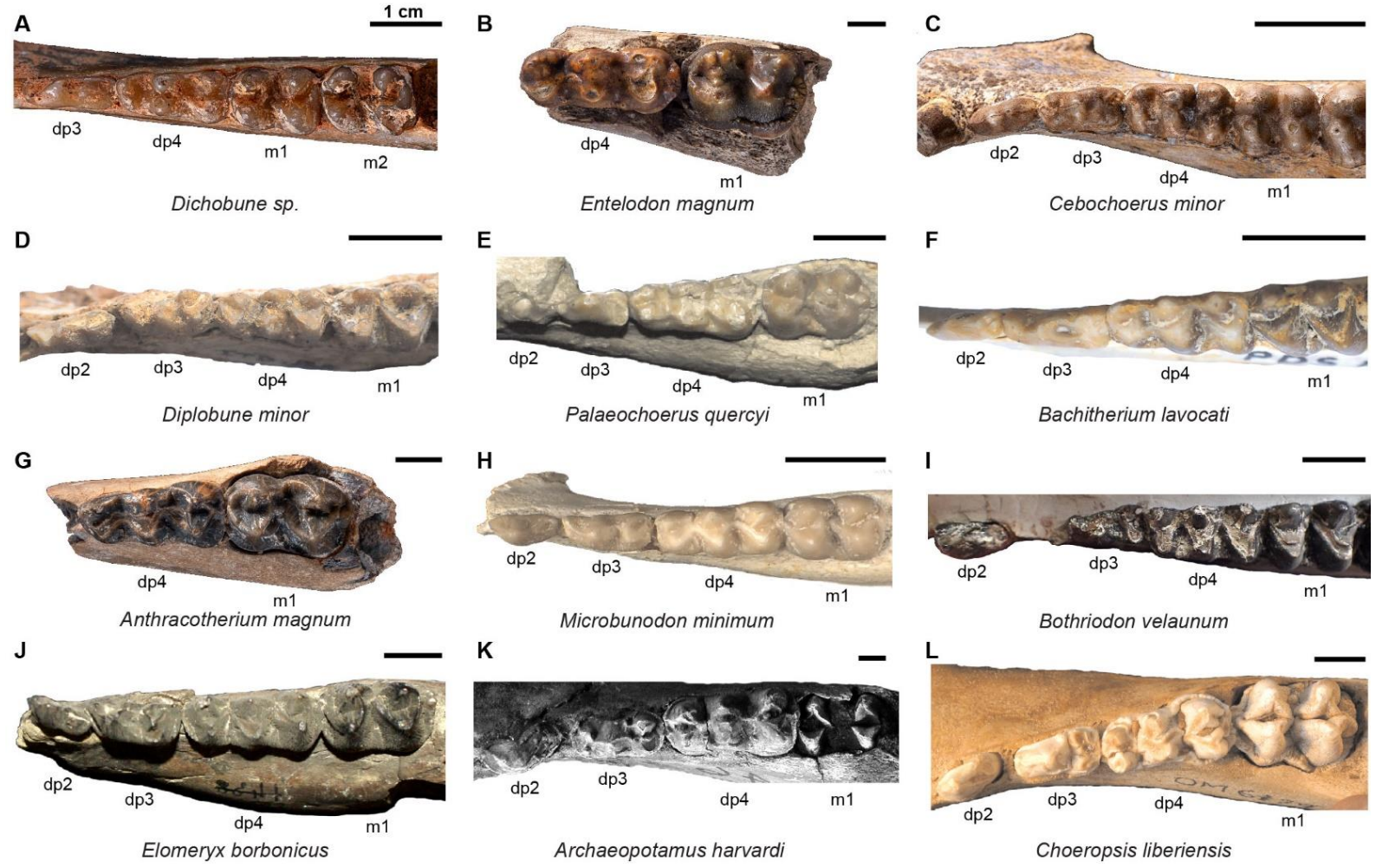
Figure 3 Main states of dental eruption (character 183), dental cusp nomenclature, characters used for deciduous premolars (184-221), and main variations of the occlusal pattern observed in cetartiodactyl jaws. The characters supporting a close relationships between some anthracotheriids and hippopotamids are depicted in red. A 3D microtomographic reconstruction of Diplobune minor (UM ITD41) and Microbunodon minimum (Ma236-69, modified from Gomes Rodrigues et al., 2019), B Lower deciduous premolars: dp2 1-Lophiomeryx 2Merycopotamus 3-Cebochoerus 4-Choeropsis, dp3 1-Lophiomeryx 2-Merycopotamus 3Elomeryx 4-Choeropsis, dp4 1-Bachitherium 2-Merycopotamus 3-Egatochoerus 4-Choeropsis; C Upper deciduous premolars: DP2 1-Elomeryx 2-Merycopotamus 3-Prodremotherium 4Paroxacron, DP3 1-Perchoerus, 2-Merycopotamus, 3-Prodremotherium, 4-Paroxacron. 


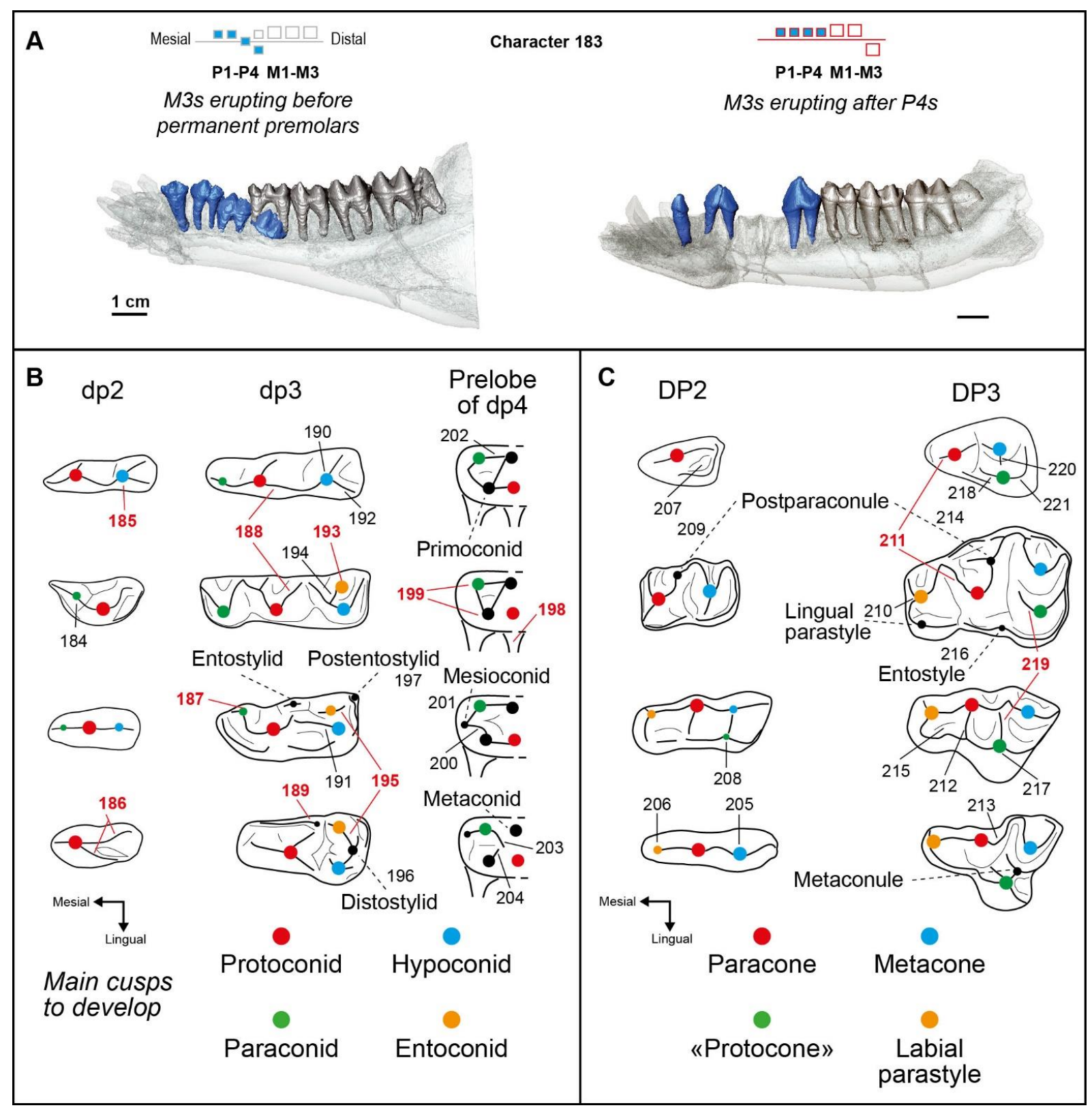


Figure 4 Phylogenetic results obtained from heuristic analyses and showing hypotheses on the relationships among hippopotamoids (“Anthracotheriidae" + Hippopotamidae in blue). A. Strict consensus tree of cetartiodactyls with characters of the deciduous dentition. Characters supporting a close relationship between some anthracotheriids and hippopotamids, and thus defining a synapomorphy of a specific clade within hippopotamoids are mentioned on blue branches. Taxa in dark green include information for more than $50 \%$ of characters for deciduous premolars, taxa in light green include information for less than $50 \%$, and data on deciduous premolars are missing for taxa in black. B. Strict consensus tree of cetartiodactyls obtained without characters of the deciduous dentition. Bremer support values $>1$ are indicated on each branch. 
A

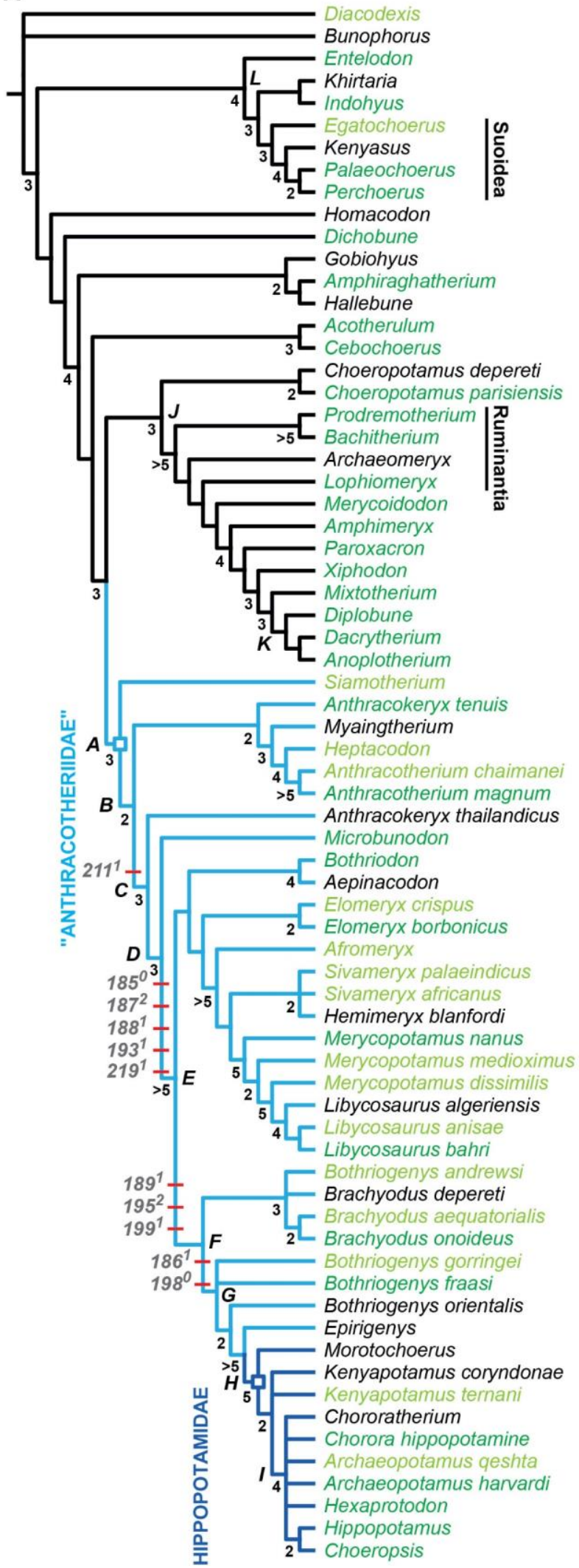

B

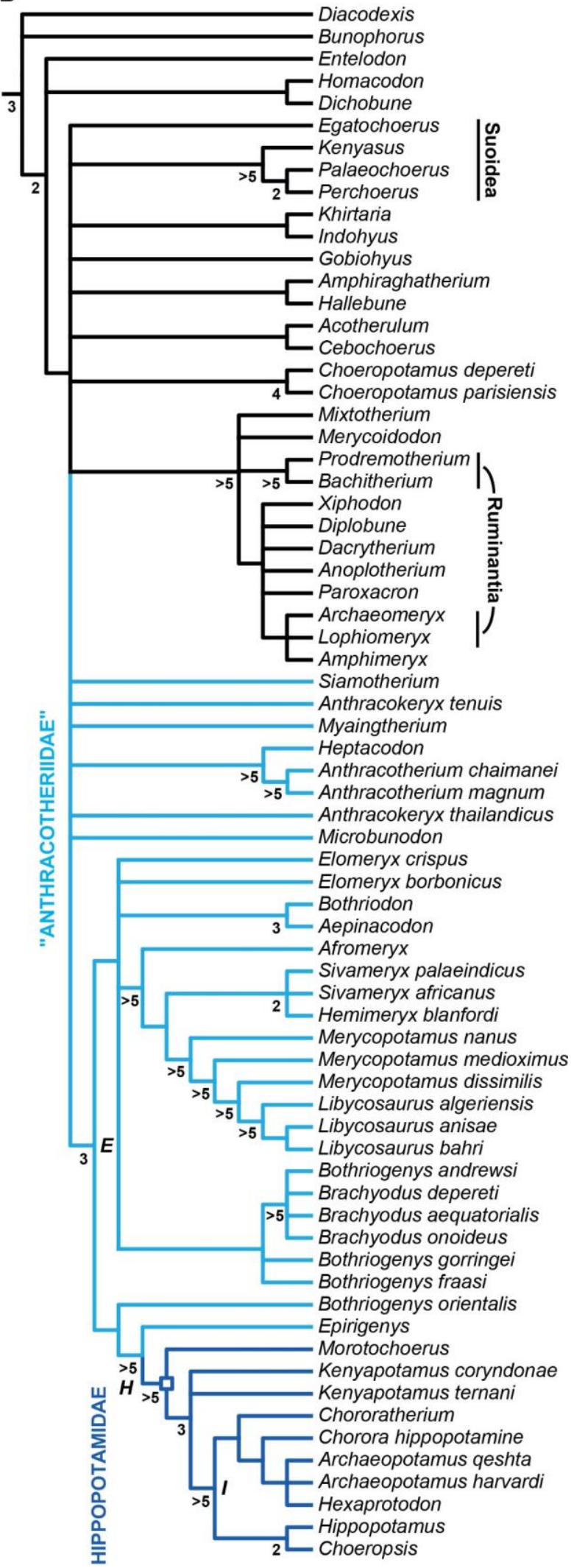


Figure 5 Maximum likelihood phylogenetic hypothesis. Bootstrap values are given at each node of the tree. Branch lengths are expressed as mean number character state changes per character. The branches in red correspond to differences with the topology resulting from the parsimony analysis including characters from the deciduous dentition (see figure 4A).

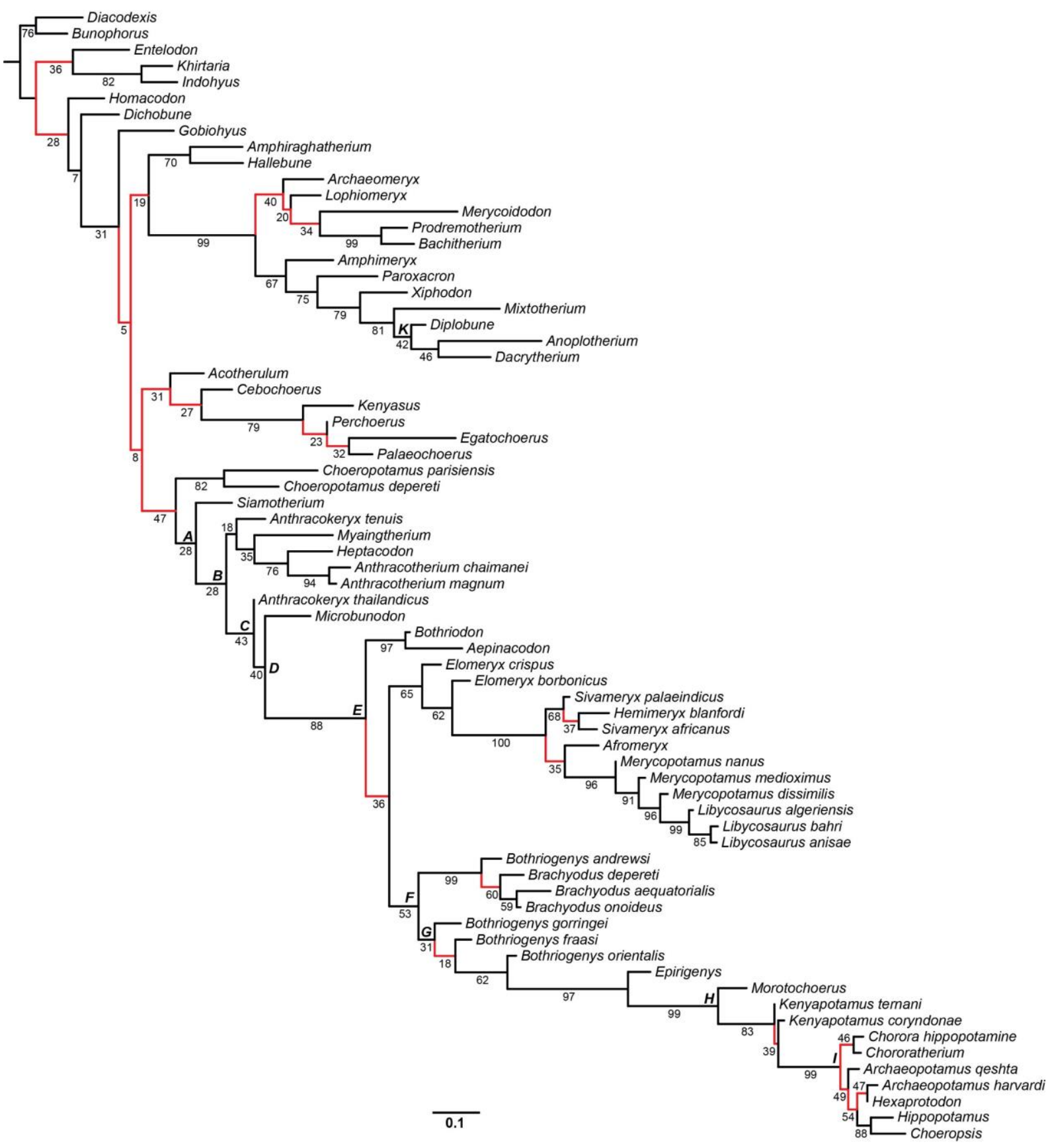


Appendix 1 List of new characters related to the deciduous dentition (and including dental eruption)

183. Eruption of M3s compared to permanent premolars:

0 . Eruption of M3s before permanent premolars

1. Eruption of M3s before or simultaneous to P4s only

2. Eruption of M3s after P4s

184. dp2 Paraconid:
$0 . \quad$ Absent
1. Mesial
2. Mesio-lingual

185. dp2 Hypoconid:

$0 . \quad$ Absent

1. Present

186. dp2 Division of the distalmost cristid:
0. Absent
1. Present

187. dp3 Paraconid:
$0 . \quad$ Absent
1. Mesial
2. Mesio-lingual

188. dp3 Postprotocristid:

0 . Distally oriented

1. Reaching the lingual side

189. dp3 cingulid on the lingual side of the protoconid:
$0 . \quad$ Absent
1. Present (or with entostylid)

190. dp3 Hypoconid:
$0 . \quad$ Absent
1. Incipient to marked

191. dp3 Prehypocristid:

0 . Longitudinal and reaching the postprotocristid

1. Lingually oriented and reaching the postprotocristid

2. Reaching the lingual side

3. Reduced to absent

192. dp3 Posthypocristid:

0 . Distally oriented

1. Labially oriented

2. Lingually oriented

3. Reaching the lingual side 
193. dp3 Entoconid:
$0 . \quad$ Absent
1. Incipient to marked

194. dp3 Preentocristid:
0 . Absent
1. Labially oriented
2. Mesially oriented

195. dp3 Postentocristid:
$0 . \quad$ Absent
1. Distally oriented
2. Labially oriented

196. dp3 Distostylid:
$0 . \quad$ Absent
1. Present

197. dp3 Post-entostylid:
0 . Absent
1. Small disto-lingual cingulid
2. Present

198. dp4 Root under protoconid:
$0 . \quad$ Absent
1. Coalescent with the mesial root
2. Present

199. dp4 Position of paraconid (lingual) vs primoconid (labial):
$0 . \quad$ Paraconid more mesial
1. Same level
2. Paraconid more distal

200. dp4 Preprimocristid:

$0 . \quad$ Reduced to absent

1. Enlarged toward the mesio-lingual side

2. Connected to the preparacristid mesially

3. Connected to the preparacristid lingually

201. dp4 Mesioconid:
$0 . \quad$ Absent
1. Stylar
2. $\quad$ Marked

202. dp4 Postparacristid:

0 . Enlarged and directed toward premetacristid

1. Reduced to absent

203. dp4 Postectoparacristid:

0 . Absent 
1. Present

204. dp4 Postprimocristid:

0 . Directed distally

1. Directed disto-lingually

2. Reaching the lingual side

205. DP2 Metacone:
0. Absent
1. Crested
2. Marked

206. DP2 Parastyle:
0. Absent
1. Present

207. DP2 Lingual basin:
$0 . \quad$ Absent
1. Disto-lingual

208. DP2 Protocone:
$0 . \quad$ Absent
1. Present

209. DP2 Postparaconule:
$0 . \quad$ Absent
1. Present

210. DP3 Anterior lobe:
0. Presence of a mesial cingulum
1. Developed with a parastyle
2. With two cusps

211. DP3 Preparacrista:
0 . Mesially oriented
1. Mesio-labially oriented
2. Mesio-lingually oriented

212. DP3 Endoparacrista:
0. Absent
1. Present

213. DP3 Postparacrista:
0. Distally oriented
1. Labio-distally oriented

214. DP3 Postparaconule:
$0 . \quad$ Absent
1. Present 
215. DP3 Mesio-lingual basin:
$0 . \quad$ Absent
1. Present

216. DP3 Entostyle:
$0 . \quad$ Absent
1. Present

217. DP3 Position of the protocone:
$0 . \quad$ At the level of the metacone
1. Between the paracone and the metacone

218. DP3 Connection of preprotocrista:
0 . No connection
1. Connected to the lingual cingulum (or entostyle)
2. Reaching the base of the paracone

219. DP3 Protocrista protruding mesio-lingually in the valley:
$0 . \quad$ No
1. Moderate
2. Elongated

220. DP3 Connection Protocone-metacone:
$0 . \quad$ Absent
1. Incomplete to complete

221. DP3 Postprotocrista:

$\begin{array}{ll}0 . & \text { Absent } \\ \text { 1. } & \text { Present }\end{array}$ 